\title{
BAZIČNA STRUKTURA LIČNOSTI I KRIMINALITET
}

\author{
Janko Međedović ${ }^{1}$ \\ Filozofski fakultet Kosovska Mitrovica
}

Tokom poslednje dve dekade ličnost je zasigurno jedan od najznačajnijih eksplanatornih konstrukata koji postoje u kriminologiji. U proučavanju crta ličnosti koje generišu kriminogena i antisocijalna ponašanja, posebna pažnja posvećuje se bazičnoj strukturi ličnosti. Postojeći modeli bazične strukture su uglavnom robusni, empirijski dobro utemeljeni i teorijski zasnovani na raznovrsnim konceptima. Postoje mnogobrojni podaci o povezanosti bazične strukture i različitih oblika kriminaliteta, ovi nalazi su relativno konzistentni i replikabilni.

U ovom radu će biti prikazane osnovne postavke nekoliko modela bazične strukture ličnosti i prezentovana istraživanja koje govore o njihovoj povezanosti sa kriminalitetom. Na prvom mestu, prikazana je Ajzenkova teorija ličnosti, kao predvodnik ovog pravca istraživanja u kriminologiji tokom šezdesetih $i$ sedamdesetih godina. Zatim je predstavljen Telegenov model, kao i rad Marvina Zakermana sa dispozicijom koju je nazvao Traženje Senzacija. Međutim, posebna pažnja posvećena je Petofaktorskom modelu kao trenutno dominantnom konceptu kada je u pitanju bazični prostor ličnosti. Kao što je opisano u radu, i u polju kriminaliteta ovaj model se pokazuje kao uspešan eksplanatorni konstrukt. Na kraju je opisan HEXACO model sa akcentom na faktoru Poštenja/Skromnosti, kao obećavajućem istraživačkom konceptu za buduća istraživanja o odnosu bazičnih dimenzija ličnosti i kriminaliteta.

Ključne reči: bazične dimenzije ličnosti, kriminal, antisocijalno ponašanje

\footnotetext{
1 jankomed@yahoo.com
} 


\section{Uvod}

Psihološko proučavanje kriminaliteta datira od početka dvadesetog veka. Nastavlja se na antropometrijska proučavanja Lombroza i Goringa koji je već 1913. postavio hipotezu da kriminogene osobe funkcionišu sa sniženim intelektualnim kapacitetima (Goring 1913, po Hollin, 1989), što i danas važi kao prihvaćen nalaz. Prva teorija ličnosti upotrebljena kao teorijski okvir za eksplanaciju kriminogenog ponašanja bila je psihoanaliza. Tako je Ajhorn ponudio strukturu ličnosti delinkvenata koja se bazira na "principu zadovoljstva," odnosno hedonističkoj motivaciji i agresivnosti koje nastaju usled neuspešnih socijalizacijskih procesa (Aichorn, 1925/1955 po Hollin, 1989).

Međutim, prva teorija ličnosti koja je u svom konceptualnom okviru sadržala i eksplicitnu teoriju kriminaliteta bila je teorija Hansa Ajzenka (Eysenck, 1977, po van Dam et al. 2005). Ova uticajna teorija je bila dominantna istraživačka paradigma u psihološkom istraživanju kriminaliteta, na osnovu nje je sakupljeno mnoštvo empirijskih nalaza (od kojih su neki potvrđivali a neki osporavali osnovne Ajzenkove pretpostavke), a može se reći i da je danas uticajna (Cale, 2006).

Psihološke teorije ličnosti su prvobitno kriminogene osobe predstavljale kao devijantne individue nudeći kao uzroke ovakvog ponašanja mentalnu insuficijenciju ili bolest, kao i antisocijalne karakteristike ličnosti poput psihopatije. Smatrajući ovakvo viđenje kriminaliteta pojednostavljenim i netačnim (i reagujući protiv biološkog redukcionizma u kriminologiji), jedan deo kriminologa se početkom druge polovine dvadesetog veka distancirao od proučavanja kriminaliteta preko ispitivanja individualnih razlika. Oni su se okrenuli socijalnim faktorima, smatrajući ih za validniji i bogatiji teorijski okvir u proučavanju kriminala (Hollin, 1989). Međutim, kako je metodološki i statistički arsenal psihologa $u$ istraživanju individualnih razlika rastao, sve više se povećavao i broj empirijskih nalaza koji su nedvosmisleno potvrđivali značaj ličnosnih dispozicija kao generatora kriminogenog ponašanja (Gottfredson and Hirschi, 1990 po Romero et al., 2001). Pošto se ličnost vratila u žižu proučavanja kriminogenog i antisocijalnog ponašanja, rastao je broj empirijskih nalaza koji povezuju strukturu ličnosti i kriminalitet. Ovaj rad ima za cilj da prezentuje neke od dominantnih koncepcija strukture ličnosti i njihove relacije sa kriminogenim ponašanjem. 


\section{Metodološka napomena: kriterijumske grupe protiv self report indikatora}

Većina istraživanja koja se bave ovom temom koristi nacrte u kojima se skorovi na testovima ličnosti koje su postigli subjekti u kriterijumskoj grupi ${ }^{2}$ (najčešće osuđenici na služenju zatvorske kazne), porede sa skorovima ispitanika koji pripadaju kontrolnoj grupi (odnosno osobe za koje ne postoji znana istorija delinkventnog ponašanja). Kejl navodi najmanje tri metodološke zamerke ovakvom tipu nacrta (Cale, 2006):

1. Zatvorenici na odsluženju zatvorske kazne su samo deo populacije koju karakteriše kriminogeno ponašanje. Postoje dva razloga na osnovu kojih bi se mogla postaviti hipoteza da je struktura ličnosti ovih osoba značajno drugačija od delinkvenata koji nikada nisu hapšeni, odnosno onih koji nisu bili na odsluženju zatvorske kazne. Prvi je zasnovan na samoj činjenici da određene sposobnosti i crte ličnosti mogu biti odgovorne da osobe izbegnu hapšenje, kao što je inteligencija na primer, ili nepostojanje Impulsivnosti i emocionalne nestabilnosti uopšte (tako i nalaz da kriminogene osobe postižu niže skorove na testovima inteligencije važi samo za osuđeničku populaciju i pitanje je da li se može generalizovati na celokupnu populaciju kriminalaca). Dakle uhapšenici čine samo deo populacije osoba koje produkuju kriminogeno ponašanje i moguće je da je ona specifična u pogledu strukture ličnosti. Drugo, samo smeštanje u ustanovu zatvorskog tipa je važna konfundirajuća varijabla kada je u pitanju ispitivanje crta ličnosti, jer dobijeni skor je modifikovan uticajem institucije na osobu. Na primer postoje podaci da intenzitet dimenzije Ekstraverzija opada sa hapšenjem i smeštanjem u ustanovu (Allsopp \& Feldman, 1974; Forrest, 1977; Haapasalo, 1990 po Cale, 2006). Zbog ovoga je teško utvrditi da li je dobijeni skor na merama ličnosti povezan sa kriminogenim ponašanjem ili sa institucionalizacijom (Romero et al. 2001).

2. Kontrolna grupa u ovakvim nacrtima se uglavnom sastoji od ispitanika protiv kojih nikada nije vođen prekršajni ili krivični postupak. Međutim ovo ne znači da osobe u kontrolnoj grupi ne emituju delinkventno ponašanje. Neki autori smatraju da nije opravdano koncipirati kriminalitet kao dihotomnu varijablu već kao kontinualnu, gde bi se uhapšenici nalazili bliže jednom kraju ove dimenzije a ispitanici u kontrolnoj grupi na suprotnom polu (Eysenck \& Gundjonsson, 1989).

\footnotetext{
${ }^{2}$ Izraz kriterijumska grupa je korišćen kao prevod engleskog termina "'known groups design."
} 
3. Kao treća zamerka u ovakvom tipu dizajna navodi se da dve grupe koje se porede najčešće nisu ujednačene po svim važnim karakteristikama koje mogu uticati na ponašanje. Ovo se pogotovo odnosi na demografske varijable.

Zbog ovakvih ograničenja neki istraživači smatraju da je umesto faktorijalnog dizajna umesnije koristiti korelacioni, a kao meru delinkventnog ponašanja uzeti skor sa nekog od self-report upitnika namenjenih za merenje delinkvencije (Furnham \& Thompson, 1991; Powell, 1977 po Cale, 2006). U ovakvom nacrtu nema podele ispitanika po grupama, tako da nema potrebe ni za ujednačavanjem grupa, nema konfundirajućeg efekta institucije, a delinkventno ponašanje se posmatra kao kontnuum.

I pored ovakvih prednosti koje bi korelacioni nacrt mogao da ima, smatramo da je istraživanje kriminogenog ponašanja pomoću kriterijumskih grupa opravdano iz nekoliko razloga: 1. pripadnost osuđeničkoj populaciji je bihejvioralni kriterijum; ispoljenom ponašanju treba dati prednost nad merama samoprocene jer su one uvek zasićene manjim ili većim efektom samoprezentacije; 2. to se posebno odnosi na merenje ponašanja koje ima visoku dimenziju socijalne poželjnosti (odnosno nepoželjnosti) kao što je kriminogeno ponašanje. Upravo zbog ovoga ispitanici mogu minimizirati antisocijalno i delinkventno ponašanje pri samoproceni jer je ono društveno nepoželjno (Eysenck \& Gundjonsson, 1989); 3. Teže oblike kriminogenog ponašanja kao što su seksualni delikti, teške krađe ili ubistva, moguće je istraživati jedino preko ovakvih tipova nacrta, self-report mere tu nisu podesne. Što se tiče metodoloških ograničenja koja istraživanja preko kriterijumskih grupa imaju, njih treba prevazilaziti metodološkim sredstvima: ujednačavanje grupa je neophodan uslov pri poređenju skorova, a pri generalizaciji nalaza opreznost je poželjna u svim psihološkim ispitivanjima, ne samo onim koja se bave ovom temom.

\section{Ajzenkova teorija ličnosti i kriminalitet}

Teorija ličnosti Hansa Ajzenka polazi od rezultata faktorske analize i definisanjem neurofizioloških korelata ekstrahovanih faktora. Faktori su konceptualizovani kao dimenzije ličnosti, a ne tipovi, dakle svaka osoba poseduje mesto na kontinuumu merene dimenzije. Bazični prostor ličnosti Ajzenk je odredio pre svega pomoću dve dimenzije - Ekstraverzija i Neuroticizam, da bi ovim faktorima u svom kasnijem radu dodao i Psihoticizam (Eysenck and Eysenck, 1976).

Konceptualizacija Ekstraverzije se zasniva na Pavlovljevim eksperimentima sa klasičnim uslovljavanjem i radu Moskovske fiziološke škole. Njenu srž čini 
postavka da postoje individualne razlike u pragu draži na koje centralni nervni sistem reaguje, odnosno stepenu njegove pobudljivosti (arousal). Ekstraverti su osobe koje imaju viši prag pobuđenja, te su prinuđeni da stalno traže nove stimulacije, i kod njih je sticanje uslovnih reakcija otežano (Cale, 2001). Neuroticizam predstavlja emocionalnu nestabilnost, nesposobnost da osoba prevlada stres i tendenciju ka generisanju depresivnih, anksioznih i drugih proneurotskih stanja. Zasnovana je na karakteristikama autonomnog nervnog sistema kao i funkcionisanju hipotalamusa i limbičkog sistema. Psihoticizam je formulisan da opiše pro-psihotične crte ličnosti. Osobe sa visokim Psihoticizmom po Ajzenku su hladne, neempatične, agresivne, egocentrične i često emituju Impulsivna i antisocijalna ponašanja (Eysenck \& Eysenck, 1976).

Što se tiče odnosa između faktora ličnosti i antisocijalnog i delinkventnog ponašanja, Ajzenk je postavio hipotezu da osobe koje produkuju ovakva ponašanja poseduju visoko izražena sva tri faktora ličnosti. Visoku Ekstraverziju kod delinkvenata obrazlagao je time da smanjena mogućnost učenja uslovljavanjem, koja odlikuje Ekstraverte, otežava formiranje savesti, čija je funkcija upravo da inhibira antisocijalna i amoralna ponašanja. Visok Neuroticizam kod delinkvenata odgovoran je za burne i neodgovarajuće reakcije (Eysenck, 1996), ali ulogu ove dimenzije Ajzenk je video prvenstveno u interakciji sa Ekstraverzijom. Međutim, po samoj svojoj definiciji Psihoticizam bi teorijski trebalo da u najvećoj meri bude odgovoran za generisanje kriminogenog ponašanja: agresivnost, nesposobnost empatije pa i propsihopatske sklonosti koje se takođe nalaze među deskriptorima Psihoticizma, su u Ajzenkovoj teoriji najbolji kandidati za konstituente ličnosti kriminalaca.

Istraživanja koja su za cilj imala da empirijski testiraju povezanosti Ajzenkovih faktora sa antisocijalnim i kriminogenim ponašanjem nisu u potpunosti podržala njegove hipoteze. Ovo se pre svega odnosi na dimenziju Ekstraverzije. U nekoliko meta-analitičkih studija nije bilo značajnih povezanosti ovog faktora sa kriterijumskim ponašanjem ili je ona bila slaba (Passingham, 1972; Cochrane, 1974 po Cale, 2006). U studiji Milera i Lajnama Ekstraverzija je korelirala sa antisocijalnim ponašanjem veoma nisko: od .01 do .1 (Miller and Lynam, 2001). Već je pomenuto da postoje nalazi koji govore da hapšenje prestupnika i smeštanje u ustanovu smanjuje skorove na ovoj dimenziji: pojava poznata kao Efekat hapšenja. Tako je u studiji Milera i Lajnama dobijeno da je povezanost Ekstraverzije i antisocijalnog ponašanja bila veća u istraživanjima gde je ovo ponašanje mereno preko self-report izveštaja, nego u onima gde su korišćene kriterijumske grupe. Ajzenk je specifikovao uticaj Ekstraverzije na kriminogeno ponašanje, smatrajući da Ekstraverzija veći uticaj ima kod mladih prestupnika. Mnogobrojna istraživanja pokazuju da je ova pretpostavka 
plauzibilna. Na primer u istraživanju Mofita i saradnika razlikuju se dve vrste delinkventnog ponašanja: delinkvencija vezana za adolescenciju i delinkvencija koja traje tokom celog životnog toka (Moffitt et al. 1996). Kod ispitanika koji manifestuju prvu vrstu delinkventnog ponašanja javljaju se crte ličnosti koje predstavljaju ekspresije Ekstraverzije: asertivnost, socijabilnost, sposobnost da se utiče na druge i preuzme uloga vođe. Takođe, čini se da je Ekstraverzija prisutna kod blažih oblika delinkventnih ponašanja: prevara, lakih krađa itd. Kod težih kriminalnih činova javljaju se karakteristike ličnosti koje upućuju na probleme u socijalnim odnosima (Cale, 2006). Ekstraverzija je takođe povišena kod recidivista (van Dam et al., 2005), što se objašnjava time da neke karakteristike ličnosti Ekstraverata utiču na to da oni bivaju hapšeni u većoj meri od introverata (Impulsivnost, socijabilnost, traženje stimulacija i uzbuđenja).

Nalazi vezani za Neuroticizam takođe ne podržavaju nedvosmisleno Ajzenkove pretpostavke, međutim postoji veći broj istraživanja koji potvrđuje ovakvu povezanost u odnosu na Ekstraverziju: u meta-analizi Milera i Lajnama korelacije Neuroticizma i antisocijalnog ponašanja se kreću između .23 i .39. (Miller and Lynam, 2001). Ajzenk je predložio hipotezu da Neuroticizam pojačava naučene oblike ponašanja, te će tek kod starijih prestupnika igrati značajnu ulogu u generisanju kriminogenog ponašanja (time je i objašnjavao interakciju Neuroticizma i Ekstraverzije). Ovakvu pretpostavku potvrdila je i analiza koju su izvršili on i Gudjonsen mada ona poseduje metodološku manu o kojoj je već bilo reči: kriterijumsko ponašanje je operacionalizovano kroz dizajn kriterijumskih grupa kod starijih prekršioca, a putem self report mera kod mlađih, te različita operacionalizacija varijabli može imati konfundirajuči efekat na rezultate (Eysenck \& Gundjonsson, 1989). Međutim i meta-analiza koju je izvršila Kejl podržava pretpostavku o Neuroticizmu kao važnom faktoru pri generisanju kriminogenog ponašanja kod starijih prestupnika (Cale, 2006). Stepen uticaja ove dimenzije na ponašanje prestupnika, posredovan je i polom: veća povezanost ove dimenzije i kriminogenog ponašanja uočena je kod osoba ženskog pola (Romero et al., 2001, Miller and Lynam, 2001).

Što se tiče Psihoticizma, ova dimenzija ličnosti se pokazala kao dosledan i stabilan prediktor kriminogenog i antisocijalnog ponašanja (Feldman 1977; Furnham \& Thompson, 1991; Perez, 1986 po Romero et al 2001). Sa obzirom da je predmet merenja Ajzenkovih skala Psihoticizma Impulsivnost, agresivnost i pro-psihopatske karakteristike ličnosti, ovakvi nalazi ne iznenađuju. Kako bi eliminisali mogućnost da je ova povezanost tautološka, odnosno da je došlo do prediktor-kriterijum kontaminacije, Romero i saradnici su nakon računanja korelacija između originalne skale Psihoticizma i antisocijalnog ponašanja, 
izbacili iz P skale sve ajteme koji u sebi sadrže deskripciju samog antisocijalnog ponašanja. Korelacije između Psihoticizma i modaliteta antisocijalnog ponašanja (vandalizam, krađe, agresivnost, kršenje pravila, konzumiranje ili prodavanje narkotika) se nisu značajno promenile, što potvrđuje validnost Psihoticizma kao prediktora ovakvog ponašanja (Romero et al. 2001). Psihoticizam je posebno uspešan prediktor kada je u pitanju kriminogeno ponašanje mlađih prestupnika. Jedan od mogućih uzroka ovakvog nalaza je i to da Impulsivnost opada sa protokom vremena (Farrington, 1994, 1995; Hare, 1996 po Cale, 2006). Psihoticizam se dalje često identifikuje kao faktor koji je povezan sa težim oblicima kriminogenog ponašanja, onima koji uključuju nasilje, kao i seksualnim deliktima (Heaven et al., 2004). I konačno, Psihoticizam se pojavljuje kao uspešan prediktor recidivizma (van Dam et al., 2005).

Tabela 1. Povezanosti Ajzenkovih faktora ličnosti sa antisocijalnim ponašanjem (podaci preuzeti iz Cale, 2006).

\begin{tabular}{llll}
\hline Dizajn kriterijumskih grupa & k & N & R \\
\hline Dimenzija ličnosti & & & \\
Ekstraverzija/socijabilnost & 25 & 5236 & .04 \\
Neuroticizam/emocionalnost & 26 & 5365 & .17 \\
Impulsivnost/Dezinhibicija & 26 & 5365 & .36 \\
\hline
\end{tabular}

Oznake: k- broj uzoraka upotrebljen u meta analizi, N- ukupan broj ispitanika, Rstandardizovana srednja vrednost korelacije između faktora i kriterijumskog ponašanja

U tabeli su prikazani rezultati meta analize koju je izvršila Kejl. Kriterijumske grupe su nacrti u kojima su kao mere ličnosti uzimani Ajzenkovi faktori, operacionalizovani instrumentom EPQ. Dobijeni podaci su potpuno konzistentni sa nalazima do kojih su došli Miler i Lajnam (Miller and Lynam, 2001). Povezanost Psihoticizma i kriterijumskog ponašanja je najveća, zatim Neuroticizma, a veza Ekstraverzije i antisocijalnog ponašanja je skoro zanemarljiva. Međutim, kako je već pomenuto u prethodnom tekstu, pri analizi je važno uzeti u obzir moderatorske varijable pola, starosti i težine izvršenog krivičnog dela, odnosno antisocijalnog ponašanja.

\section{Jedno poređenje: Ajzenkov i Telegenov model}

Telegenova istraživanja ličnosti nisu imala nameru niti da postave novi model strukture ličnosti, niti da formulišu novi omnibus instrument za procenu i eksploraciju ličnosti. Cilj njegovih proučavanja je bio da razjasni teorijske nedoumice oko faktora koji su se uvek pojavljivali kao dimenzije višeg reda $u$ istraživačkim radovima (poput Ekstraverzije i Neuroticizma), da razjasni od- 
nose primarno ekstrahovanih faktora u okviru ovih dimenzija i da se još jednom priđe problemu metrijskih karakteristika različitih instrumenata za procenu ličnosti (Tellegen and Waller, 2008). Međutim, njegova faktorska istraživanja dovela su do koncipiranja jedanaest dimenzija ličnosti čiji se sadržaj u izvesnom obimu preklapa sa konstruktima drugih autora. To su sledeće dimenzije: Zadovoljstvo životom ili blagostanje, Socijalna potencija, Postignuće, Socijalna bliskost, Reakcija na stres, Otuđenje ili alijenacija, Agresivnost, Kontrola, Izbegavanje opasnosti, Tradicionalizam i Apsorpcija. Ove, primarne crte ličnosti, sačinjavaju tri ortogonalna faktora višeg reda koji poseduju sledeće nazive: Pozitivna emocionalnost-PEM (čine ga dimenzije blagostanje, socijalna potencija, postignuće i socijalna bliskost), Negativna emocionalnost-NEM (reakcija na stres, alijenacija i agresivnost) i Suzdržavanje-CON (izbegavanje opasnosti, tradicionalizam i kontrola). Dimenzija apsorpcije se nalazi van okvira faktora višeg reda (Patrick et al., 2002).

Grupa autora (Krueger et al.,1994) je izvršila istraživanje sa namerom da proceni povezanosti crta ličnosti dobijenih u Telegenovim istraživanjima i kriminogenog ponašanja. Ovaj istraživački pokušaj posebno vrednim čini operacionalizovanje kriterijumskog ponašanja preko četiri izvora: self report mera, informacija dobijenih od nezavisnih izvora (rodbina, prijatelji itd.), podataka iz policijskih izveštaja i podataka o sudskim presudama. Tražene su robusne karakteristike ličnosti koje su dosledno povezane sa kriminalitetom, odnosno crte koje su značajno povezane sa kriterijumskim ponašanjem kroz različite izvore podataka o delinkvenciji. Rezultati njihovog istraživanja prezentovani su u tabeli 2 .

Iz tabele se vidi da su tri dimenzije ličnosti značajno povezane sa kriminalitetom kroz tri različita izvora podataka: self-report mere, informacije dobijene iz nezavisnih izvora i podataka o sudskim presudama. Delinkventno ponašanje je dosledno negativno povezano sa Tradicionalizmom i Kontrolom, a pozitivna korelacija dobijena je sa dimenzijom Agresivnost. Dakle delinkventi su nekonzervativni, niskih moralnih standarda, buntovni i bez poštovanja autoriteta, što možemo zaključiti po negativnoj povezanosti sa skalom tradicionalizma. Agresivno ponašanje je jedina crta ličnosti koja značajno korelira sa svim modalitetima delinkvencije u svakoj polnoj kategoriji, što je čini potencijalno najboljim prediktorom. Negativna korelacija sa Kontrolom govori o Impulsivnosti, nedostatku kontrole i dezinhibiranom ponašanju. Još dva faktora poseduju značajne korelacije sa delinkvencijom i to kroz sve modalitete merenja za muškarce, i kroz dva modaliteta za žene: Alijenacija (osećanje odbačenosti, nesreće, usamljenosti ali i paranoičnosti u smislu da nam drugi žele zlo) i Rea- 
kcija na stres (napetost, vulnerabilnost, promenljivost raspoloženja, depresivnost).

Tabela 2. Korelacije izmedu varijabli ličnosti i mera delinkvencije po polu (preuzeto iz Krueger et al.,1994).

\begin{tabular}{|c|c|c|c|c|c|c|c|c|}
\hline \multirow[b]{3}{*}{ Varijable } & \multicolumn{8}{|c|}{ Mere delinkvencije } \\
\hline & \multicolumn{2}{|c|}{ Self-report } & \multicolumn{2}{|c|}{ Nezavisni izvori } & \multicolumn{2}{|c|}{ Policijski izveštaji } & \multicolumn{2}{|c|}{ Sudske presude } \\
\hline & $\begin{array}{c}\text { Žene } \\
(n=417)\end{array}$ & $\begin{array}{l}\text { Muškarci } \\
(n=440)\end{array}$ & $\begin{array}{c}\text { Žene } \\
(n=379)\end{array}$ & $\begin{array}{l}\text { Muškarci } \\
(n=395)\end{array}$ & $\begin{array}{c}\text { Žene } \\
(«=418)\end{array}$ & $\begin{array}{l}\text { Muškarci } \\
(n=444)\end{array}$ & $\begin{array}{c}\text { Žene } \\
(«=414)\end{array}$ & $\begin{array}{l}\text { Muškarci } \\
(n=432)\end{array}$ \\
\hline \multicolumn{9}{|l|}{ Skale MPQa } \\
\hline Tradicionalizam & $-.34^{* *}$ & $-.37^{* *}$ & $-.12^{*}$ & $-.14^{* *}$ & -.08 & -.08 & $-.11^{*}$ & $-.16^{* *}$ \\
\hline Izbegavanje opasnosti & $-.23^{* *}$ & $-.20^{* *}$ & -.03 & -.01 & -.01 & -.02 & -.04 & -.04 \\
\hline Kontrola & $-.39^{* *}$ & $-.37^{* *}$ & $-.13^{* *}$ & $-.12^{*}$ & -.09 & $-.11^{*}$ & $-.12^{*}$ & $-.19^{* * *}$ \\
\hline Agresivnost & $.48^{* *}$ & $.52^{* *}$ & $.25^{* * *}$ & $.28^{* * *}$ & $.24^{* * *}$ & $.17^{* * *}$ & $.19^{* * *}$ & $.21^{* * *}$ \\
\hline Alijenacija & $.19^{* *}$ & $.29^{* *}$ & $.23^{* * *}$ & $20^{* * *}$ & .08 & $.18^{* * *}$ & .08 & $.18^{* * *}$ \\
\hline Reakcija na stres & $.17^{* *}$ & $.26^{* *}$ & $.23^{* * *}$ & .07 & .06 & $.12^{* *}$ & .01 & .03 \\
\hline Postignuće & $-.13^{* *}$ & 0 & -.01 & -.06 & $-.13^{* *}$ & -.01 & $-.13^{* *}$ & -.02 \\
\hline Socijalna potencija & $.23^{* * *}$ & $.21^{* * *}$ & .09 & .09 & -.03 & -.02 & .01 & .03 \\
\hline Blagostanje & -.04 & .05 & $-.11^{*}$ & .02 & -.01 & -.01 & -.04 & -.04 \\
\hline Socijalna bliskost & -.08 & -.08 & $-.12^{*}$ & .01 & -.01 & -.04 & -.02 & -.03 \\
\hline R & $.57^{* * *}$ & $.63^{* * *}$ & $.35^{* * *}$ & $.34^{* * *}$ & $.29^{* * *}$ & $.23^{* *}$ & $.24^{* *}$ & $.30^{* * *}$ \\
\hline \multicolumn{9}{|l|}{ Faktori višeg reda } \\
\hline Suzdržavanje & $-.44^{* * *}$ & $-.44^{* * *}$ & $-.13^{*}$ & $-.12^{*}$ & -.07 & -.09 & $-.13^{* *}$ & $-.17^{* * *}$ \\
\hline Negativna emocionalnost & $.34^{* * *}$ & $.48^{* * *}$ & $.32^{* * *}$ & $.23^{* *}$ & $.15^{* *}$ & $.20^{* * *}$ & .09 & $.17^{* * *}$ \\
\hline Pozitivna emocionalnost & .01 & .05 & -.05 & .03 & -.08 & -.04 & -.09 & -.04 \\
\hline R & $.50^{* * *}$ & $.58^{* * *}$ & $.33^{* * *}$ & $.24^{* * *}$ & $.17^{* *}$ & $.20^{* * *}$ & $.16^{* *}$ & $.21^{* * *}$ \\
\hline
\end{tabular}

Napomena:Zvezdice označavaju intervale poverenja: ${ }^{*} p<.05,{ }^{* *} p<.01,{ }^{* * *} p<.001$.

Što se faktora višeg reda tiče, Negativna emocionalnost je ta koja je sistematski povezana sa svim merama delinkvencije (najzad sve tri dimenzije koje čine ovaj faktor su pokazale dosledne povezanosti). Suzdržavanje negativno korelira sa svim modalitetima sem sa podacima dobijenim iz policijskih izveštaja. Pozitivna emocionalnost nije pokazala povezanost sa kriterijumskim ponašanjem.

Jasno je da se može napraviti paralela između Telegenovog i Ajzenkovog modela. Predmet merenja Pozitivne emocionalnosti se preklapa sa Ekstraverzi- 
jom, Negativne sa Neuroticizmom, dok Suzdržavanje ima sličan predmet merenja kao dimenzija Psihoticizma (Cale, 2006). Zbog sličnosti faktora višeg reda, u već pomenutoj meta-analizi Kejlove poređeni su Ajzenkov i Telegenov model i njihove povezanosti sa antisocijalnim ponašanjem. Rezultati njene analize dati su u tabeli br. 3 .

Tabela 3. Povezanost Ajzenkovih (merenih EPQ inventarom ličnosti) i Telegenovih faktora (merenih MPQ instrumentom) sa antisocijalnim ponašanjem.

\begin{tabular}{llll}
\hline Dimenzija ličnosti & $\begin{array}{l}\text { Instrument } \\
\text { (model) }\end{array}$ & $k$ & $r$ \\
\hline \multirow{2}{*}{ Ekstraverzija/socijabilnost } & EPQ & 46 & .15 \\
& MPQ & 14 & .03 \\
Neuroticizam/emocionalnost & $\mathrm{EPQ}$ & 42 & .21 \\
& $\mathrm{MPQ}$ & 14 & .26 \\
Impulsivnost/Dezinhibiranost & $\mathrm{EPQ}$ & 48 & .46 \\
& $\mathrm{MPQ}$ & 14 & .29 \\
\hline
\end{tabular}

Oznake: k- broj uzoraka upotrebljen u meta-analizi, $r$-korelacije između faktora i kriterijumskog ponašanja

Ajzenkova E dimenzija je povezana sa antisocijalnim ponašanjem u značajno većoj meri nego PEM. Ovaj nalaz se može objasniti na dva načina. Prvi je da ajtemi Ajzenkove Ekstraverzije, za razliku od PEMa, sadrže i ajteme traženja senzacija, a ova dimenzija je povezana sa kriminogenim ponašanjem (Zuckerman, 2007). Dalje, PEM kao faktor višeg reda poseduje dva modaliteta: agensni PEM (socijalna potentnost i postignuće) i socijalni PEM čiju osnovu konstituiše socijalna bliskost (Almagor et al.,1995). Postoji hipoteza da agensni PEM zaista nije povezan sa kriminogenim ponašanjem ali da socijalni PEM negativno korelira sa istim, te prvi deluje kao supresorska varijabla (Cale, 2006). Što se tiče druge pretpostavke, iz tabele br. 2 se jasno vidi da socijalna bliskost nije značajno povezana ni sa jednim modalitetom delinkvencije (osim sa podacima dobijenim od nezavisnih izvora na ženskom poduzorku) te smatramo da se ona ne može održati.

Telegenov NEM u većoj meri korelira sa antisocijalnim ponašanjem nego Ajzenkov faktor Neuroticizma. Ovo je pre svega posledica dimenzija Agresivnosti ali i Alijenacije koje se nalaze u okviru ovog faktora višeg reda, a kojih nema u Ajzenkovom Neuroticizmu.

Što se tiče dimenzije Impulsivnost/Dezinhibiranost, odnosno Psihoticizma, faktor koji je operacionalizovao Ajzenk poseduje veće korelacije sa kriterijumskim ponašanjem nego Telegenova dimenzija Suzdržavanja. I ova razlika nas- 
taje u operacionalizovanju dva faktora: Psihoticizam sadrži ajteme agresivnosti, i pro-psihopatskih tendencija koji ne postoje kod Suzdržavanja (Cale, 2006). Zajednički predmet merenja ove dve dimenzije je Impulsivnost i nedostatak kontrole.

Dobijeni podaci $u$ istraživanju Kejlove su sasvim očekivani kada se uzme $u$ obzir operacionalizacija faktora višeg reda u ova dva modela. Očigledno je da se predmeti merenja samo delimično podudaraju kod Ajzenkovih i Telegenovih faktora. Agresivnost, koja je dominantna komponenta Psihoticizma omogućuje mu veću povezanost sa antisocijalnim ponašanjem nego ona koju poseduje Suzdržavanje. Međutim agresivnost je kod Telegena smeštena u Negativne emocije, koje zbog toga u većoj meri koreliraju sa kriterijumskim ponašanjem nego Neuroticizam. Isto važi za Alijenaciju: doživljaj da su drugi protiv nas, da nam spletkare i žele zlo se pojavljuje kao ajtem P skale kod Ajzenka i NEM faktora kod Telegena što rezultira većom povezanošću sa antisocijalnim ponašanjem ovih faktora u odnosu na njihove parnjake iz drugog modela. Ipak ovi podaci nam donose jedan važan zajednički nalaz: u oba modela agresivnost, impulsivnost i sklonost da se akcije i namere drugih interpretiraju kao ugrožavajuće, pokazuju najveći stepen povezanosti sa kriminogenim ponašanjem.

\section{Potraga za senzacijama i rizično ponašanje}

Kako kaže Marvin Zakerman, teorija o traženju senzacija, "bukvalno je počela u mraku" (Zuckerman, 2007). Reč je o mraku i tišini izolacione komore koja je njemu i njegovom timu služila za eksperimentalno ispitivanje senzorne deprivacije. Eksperimentatori su upotrebili široki konstrukt Optimalnog nivoa uzbuđenja kako bi pokušali da predvide individualne razlike u reakcijama ispitanika na senzornu deprivaciju. Traženje senzacija je crta ličnosti koja se zasniva na ovom nivou pobuđenja: izraženost ove crte označava visok prag pobuđenja, te osoba ima potrebu da traga za senzacijama i traži stimulacije ${ }^{3}$. U eksperimentu, ovakve osobe su reagovale brže i intenzivnije na senzornu deprivaciju, pokazivale veći stepen dosade i čak iskazivale veću motoričku aktivnost od ispitanika koji su imali nizak nivo pobuđenosti (Zuckerman, 2007).

$\mathrm{Na}$ osnovu početnih saznanja dobijenih u eksperimentalnim nacrtima, započeto je sa konstruisanjem skala koje bi pomoću samoprocene prikupljale podatke o traženju senzacija. Nakon nekoliko verzija instrumenta koje su pos-

\footnotetext{
${ }^{3}$ Primetna je sličnost Zakermanovog pokušaja da objasni individualne razlike u traženju senzacija sa Ajzenkovim fiziološkim tumačenjima razlika između Ekstraverata i introverata.
} 
matrale traženje senzacija kao jednu dimenziju ličnosti, prikupljeno je dovoljno nalaza koji su pokazali postojanje četiri modaliteta ove crte. Oni su se pokazali stabilnim kroz različite prevode skale i rezultate ispitanika različitih nacionalnih pripadnosti (Zuckerman, 1994). Ekstrahovani faktori su sledeći: Potraga za uzbuđenjem i avanturama (npr. bavljenje ekstremnim sportovima), Traganje za iskustvom (koja može biti izražena kroz nekonformirajući životni stil), Dezinhibicija (hedonistički životni stil, koji odlikuje zloupotreba alkohola, rizično seksualno ponašanje itd.) i Osetljivost na dosadu (averzija i uznemirenost kada se osoba nađe u monotonim i nestimulišućim uslovima). Traganje za senzacijama visoko korelira sa Impulsivnošću, te je $u$ alternativnom petofaktorskom modelu ličnosti koji je sa saradnicima razvio Zakerman, ova crta koncipirana kao Impulsivno traženje senzacija (Zuckerman, 1994).

Kriminogeno ponašanje je jedan od bihejvioralnih stilova osoba kod kojih je Traženje senzacija izraženo. Postoje različiti ličnosni kao i sredinski faktori koji u interakciji sa ovom osobinom generišu antisocijalno i kriminogeno ponašanje umesto nekog drugog. Već je pomenuto da je Impulsivnost jedna od njih. Zakerman i Horvat (Horvat and Zuckerman, 1993) su pronašli značajne korelacije između Traženja senzacija i Impulsivnosti sa jedne strane i kriminogenog ponašanja sa druge, kod studenata koledža (kriminaltet je meren self-report instrumentima). U ovom istraživanju su povezanosti između Traženja senzacija i kriminaliteta bile veće $(r=.53)$ od povezanosti Impulsivnosti i kriminaliteta $(\mathrm{r}=.36)$.

U pominjanom istraživanju koje su izvršili Romero i saradnici (Romero et al. 2001) ispitivane varijable pored Ajzenkovih faktora su bila i četiri modaliteta Traženja senzacija, kao i Impulsivnost. Kako je kriterijumsko ponšanje bilo operacionalizaovano dvostruko, i preko self-report mera i preko kriterijumske grupe ispitanika (dakle bili su ispitivani institucionalizovani i neistitucionalizovani subjekti), autori su računali korelacije između Traženja senzacija i kriminogenog ponašanja, zatim sposobnost modaliteta ove dimenzije da diskriminiše delinkvente od nedelinkvenata, kao i prediktivne sposobnosti ispitivanih varijabli u modelu multiple regresije. Rezultati su bili sledeći: Dezinhibicija u najvećoj meri korelira sa kriminalitetom (.42 za muškarce i žene), potom Traganje za iskustvom (.38 za muškarce i .36 za žene), zatim Osetljivost na dosadu (.22 za muškarce i .33 za žene) i najmanju povezanost sa kriminalitetom ostvaruje modalitet Potrage za uzbuđenjem i avanturama (.18 za muškarce i $.20 \mathrm{za}$ žene). Potom su autori podelili ispitanike u uzorku u podgrupe u zavisnosti od postignutog skora na skali delinkvencije na nedelinkventne, umereno delinkventne i izrazito delinkventne. Sve ispitivane varijable su uspele da diskriminišu ispitanike bar po nekim nivoima ovako konstruisanog fak- 
tora, u kontrolnoj grupi. Međutim kod institucionalizovanih osoba samo 4 varijable značajno diskriminišu ispitanike u odnosu na stepen delinkventnosti: Psihoticizam, Impulsivnost i dva modaliteta Traženja senzacija - Dezinhibicija i Traganje za iskustvom. Značajnost svakog od ovih faktora u predikciji kriminaliteta vidi se u regresionom modelu: kod muškaraca najznačajniji prediktori su Dezinhibicija $(\beta=.16)$, Psihoticizam $(\beta=.12)$ i Traganje za iskustvom $(\beta=.10)$. Kod žena je potpuno drugačija situacija: Značajni prediktori su Impulsivnost $(\beta=.17)$ i Ekstraverzija $(\beta=.09)$.

Čini se da su nalazi koji sugerišu da postoje dva faktora višeg reda koji stoje iza modaliteta Traženja senzacija opravdani. Prvi je Socijalizovano Traženje senzacija koje je odgovorno za ona ponašanja koja imaju za cilj da se postigne uzbuđenje na, manje-više, društveno prihvatljive načine. Drugi je Nesocijalizovano Traženje senzacija koje je dosledan generator kriminogenog i antisocijalnog ponašanja. Po nalazima samog Zakermana prvi faktor čine Potraga za uzbuđenjem i Osetljivost na dosadu a drugi Dezinhibicija i Traganje za iskustvom (Zuckerman, 2007). Kako smo videli, ova hipoteza je u saglasnosti sa nalazima koje su dobili Romero i saradnici. Potvrdu o postojanju dva faktora Traženja senzacija daju Nust i Stjuart (Knust and Stewart, 2002) ali konstituenti ova dva faktora nisu isti kao kod Zakermana. Interesantno je da su ovi autori faktorisali zajedno Ajzenkove dimenzije ličnosti i modalitete Traženja senzacija. Prvi faktor (Socijalizovane tendencije) čine Ekstraverzija, Neuroticizam, Potraga za uzbuđenjem i avanturama i Traganje za iskustvom. Nesocijalizovane oblike čine Psihoticizam, Dezinhibicija i Osetljivost na dosadu. Ovo je važna potvrda razdvajanja modaliteta Traženja senzacija na socijalizovane i nesocijalizovane oblike. Što se tiče sačinitelja ovih Nesocijalizovanih oblika, nije potpuno izvesno da li je njihov konstituent Traganje za iskustvom ili Osetljivost na dosadu, ali sasvim sigurno to jeste Dezinhibicija. Može se zaključiti da je ovo modalitet Traženja senzacija koji je najviše povezan sa kriminogenim ponašanjem. Ovu vezu potencira i sam Zakerman, navodeći da je prisustvo Dezinhibicije i agresivnosti diferencijalno dijagnostički znak psihopatije (Zukerman, 2007).

Interesantne podatke daju Horvat i Zakerman (Horvat and Zuckerman, 1993) konstruišući model koji u sebi sadrži odnose između varijabli ličnosti (odnosno Traženja senzacija), kognitivnih faktora (procene koliko je određeno ponašanje rizično u odnosu na izvršioca), sredinskih faktora (prisustvo kriminogenog ponašanja u vršnjačkoj grupi) i samog kriminogenog ponašanja (operacionalizovanog kroz self-report mere). Računate su korelacije između ovih varijabli i izložene su na dijagramu 1. 
Vidimo da kriminogeno ponašanje u vršnjačkoj grupi najviše korelira sa sopstvenim kriminogenim ponašanjem što bez sumnje ističe značaj socijalnih faktora u generisanju kriminaliteta. Iza socijalnih, idu varijable ličnosti, pre svega Traženje senzacija pa Impulsivnost i na kraju procena rizika. Ovo je redosled varijabli i kada je u pitanju predikcija kriminogenog ponašanja. Multipla regresija je pokazala da je najbolji prediktor Kriminogeno ponašanje u vršnjačkoj grupi $(\beta=0,43)$, zatim Traženje senzacija $(\beta=0,27)$, Impulsivnost $(\beta=0,13)$ i Procena rizika $(\beta=-0,15)$.

Dijagram 1. Korelacije između traženja senzacija, Impulsivnosti, sopstvenog kriminogenog ponašanja, procene rizika koji takvo ponašanje nosi i kriminogenog ponašanja u vršnjačkoj grupi. Adaptirano prema Horvat and Zuckerman, 1993.

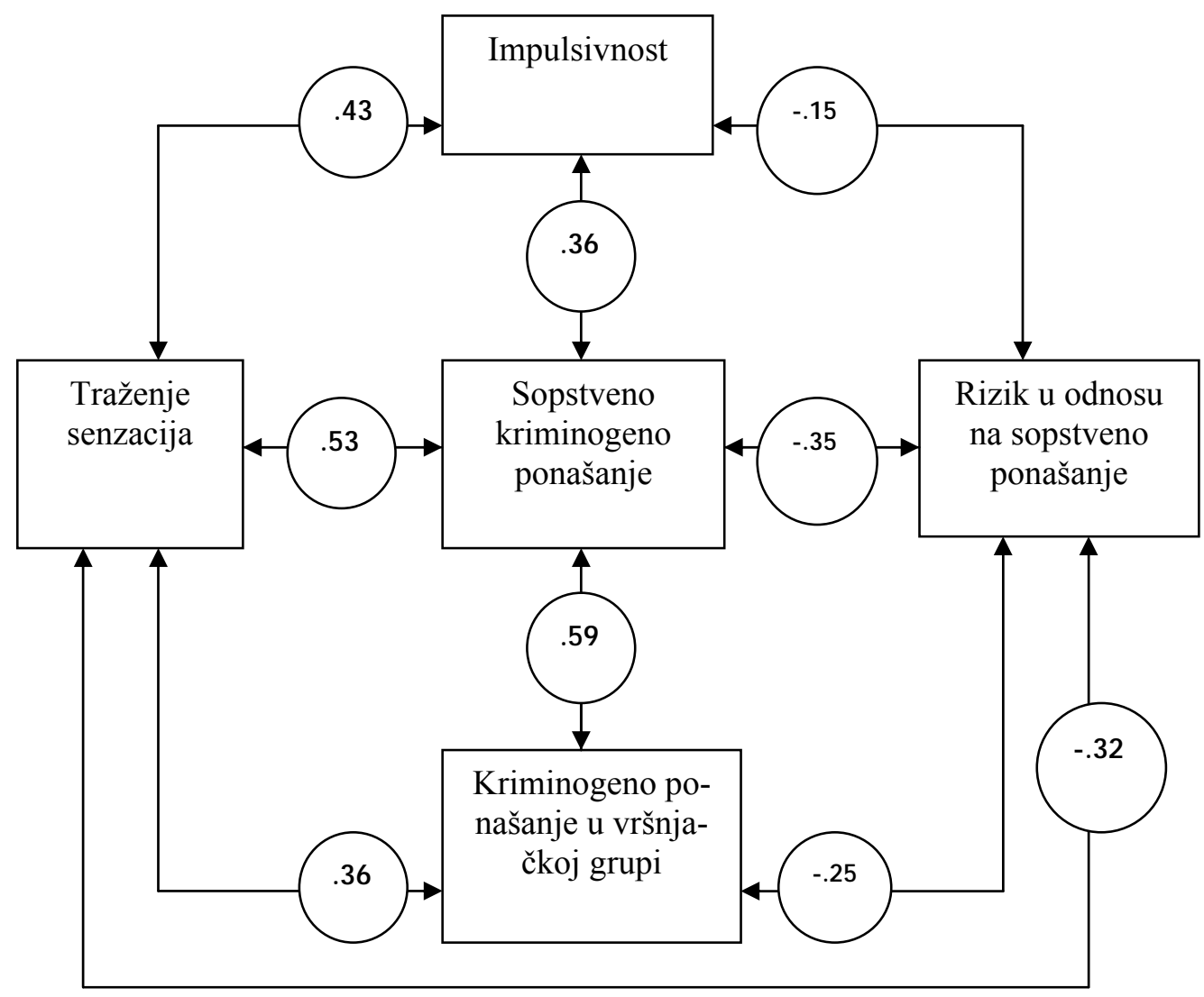




\section{Leksička hipoteza i pet faktora ličnosti}

Ajzenkova i Zakermanova teorija ličnosti nastaju u okviru psihobiološkog pristupa, odnosno pokušaja da se crte ličnosti povežu za bazičnijim fiziološkim domenima funkcionisanja organizma. Petofaktorski model je rezultat jedne druge paradigme $u$ istraživanju ličnosti, paradigme koja postaje dominantna $u$ ovom polju psihologije, jer je upravo pomoću nje postignut zavidan konsenzus među istraživačima o broju osnovnih dimenzija ličnosti (McCrae, 2001 po Wiebe 2004). U pitanju je leksička hipoteza. Ona se zasniva na pretpostavci da su svi važni opisi ličnosti utisnuti u jezičku supstancu, odnosno da se nalaze u prirodnom jeziku. Na na taj način, adekvatnim uzorkovanjem termina, može se dobiti skup opisa ličnosti koji je obuhvatan i validan i na osnovu koga ljudi mogu opisati sebe. Faktorizacijom ovakvog skupa varijabli dobijaju se latentne dimenzije koje leže u osnovi individualnih razlika kada su u pitanju crte ličnosti.

Petofaktorsko rešenje nije jedino koje je dobijeno u leksičkim istraživanjima (Saucier, 2008), ali predstavlja robustan i komprehenzivan model; pet faktora je do sada replicirano u mnogim jezičkim grupama (Costa \& McCrae, 1997 po Knežević et al. 2004) i izvedeno je mnoštvo istraživanja u kojima su utvrđene povezanosti ovog modela sa drugim konstruktima individualnih razlika. U ovom trenutku ne postoji samo jedna operacionalizacija modela ličnosti koja se bazira na pet leksičkih faktora. Sadržaji faktora koje su dali različiti autori se u velikoj meri preklapaju, ali ipak, među njima postoje i razlike. Istraživanja o kojima će se govoriti u ovom radu uglavnom su bazirana na Petofaktorskom modelu ličnosti koji su predložili Kosta i Mek Kre i instrumentima koje su oni razvili (Costa and McCrae, 1992). Kada to nije slučaj, u tekstu će biti naznačeno kako je ispitivana bazična struktura ličnosti.

Ovo su opisi pet faktora koje su koncipirali Pol Kosta i Robert Mek Kre: Neuroticizam (emocionalna nestabilnost i neprilagođenost), Ekstraverzija (aktivitet, socijabilnost, društvenost), Otvorenost (estetska osetljivost, intraceptivnost, intelektualna radoznalost), Saradljivost (poverenje, altruizam, kooperacija) i Savesnost (težnja ka ostvarenju ciljeva, disciplinovanost) ${ }^{4}$. Faktori N i E su konceptualno slični Ajzenkovim faktorima koji nose iste nazive. Otvorenost je domen koji se pojavljuje jedino u leksičkim modelima ličnosti, nijedan drugi teorijski okvir nije uspeo da izoluje dimenziju ličnosti ovakvog sadržaja. $\mathrm{O}$ je stabilan i robustan faktor i dosledno se replicira u kros-kulturalnim istra-

\footnotetext{
${ }^{4} \mathrm{U}$ daljem tekstu domeni petofaktorskog modela biće označavani po prvom slovu engleskog naziva: Ekstraverzija-E (Extraversion), Neuroticizam-N (Neuroticism), Otvorenost-O (Openness), Saradljivost-A (Agreableeness) i Savesnost-C (Conscientiousness).
} 
živanjima sa neznatno promenjenim sadržajem (u nekim drugim leksičkim modelima naziva se i Intelekt ili Kultura). Što se domena A i C tiče, Ajzenk je tvrdio da oni predstavljaju subordinirane dimenzije njegovog faktora Psihoticizma (Eysenck, 1992, po Costa and McCrae, 1995). Autori Petofaktorskog modela smatraju da A i C zaista negativno koreliraju sa Psihoticizmom, ali i da predstavljaju generatore varijanse individualnih razlika koja nije obuhvaćena Ajzenkovim faktorom, te da su nezavisni i ireducibilni bazični domeni ličnosti (Costa and McCrae, 1995).

Veliki broj studija koje su ispitivale povezanosti između petofaktorskog modela ličnosti i kriminaliteta potvrdio je značajne veze između A i C faktora i kriminogenog ponašanja. Preciznije rečeno u pitanju su negativne korelacije, dakle kriminogene ličnosti odlikuje niska saradljivost, sklonost ka prepirci i svađi, zajedljivosti ali takođe i slaba motivacija za postignućem i snižena sposobnost organizacije pri ispunjenju zadataka. Ove nalaze potvrdila je i metaanaliza Milera i Lajnama. Ova dva autora su analizirala povezanosti Ajzenkovog, Telegenovog, Klonindžerovog modela bazične strukture ličnosti, kao i Petofaktorskog modela sa antisocijalnim ponašanjem. Njihovi nalazi ne samo da potvrđuju stabilne i relativno visoke negativne povezanosti A i C faktora sa kriminalitetom, već oni smatraju da se i povezanosti crta iz drugih modela i kriterijumom mogu shvatiti kao aspekti niske Saradljivosti i Savesnosti (Miller and Lynam 2001).

Međutim, neke druge studije, pokazale su povezanosti i ostalih faktora iz petofaktorskog prostora i kriminogenog ponašanja, na taj način potvrđujući komprehenzivnost modela. Grupa istraživača (John, Caspi, Robins, Moffitt, and Stouthamer-Loeber, 1994) je na uzorku dečaka od 12 i 13 godina koji su se bavili pljačkama, prodavanjem psihoaktivnih supstanci, i generalno ispoljavali nasilničko ponašanje, dobili povezanosti sa skoro svim domenima Petofaktorskog modela. Subjekti u ispitivanom uzorku postigli su niže skorove na A, $\mathrm{C}$, i O faktorima a skor na E domenu bio je značajno viši u odnosu na kontrolnu grupu.

Van Aken, Van Liešut i Šolt su izvršili klaster analizu na skorovima Velikih pet kod adolescenata (faktori su ispitivani preko 25 bipolarnih skala koje su konstruisali sami autori). Dobijena su tri tipa ličnosti koje su autori nazvali Nekontrolisani (Undercontrolled), Snažno kontrolisani (Overcontrolled) i Otporni (Resilient), pa su zatim podeljeni u dve subgrupe: Socijalizovane i Antisocijlne (Van Aken et al, 1998). Svih šest dobijenih grupa su zatim poređeni prema skorovima na self-report instrumentima za merenje delinkvencije. Najveće skorove na samoproceni delinkvencije ostvarivali su ispitanici iz grupe Nekontrolisanih Antisocijalnih ličnosti i njih su odlikovala sledeća postignuća 
na skalama koje mere Velikih pet: ekstremno niski skorovi na A i C domenu i umereni skorovi na $\mathrm{E}, \mathrm{N}$ i $\mathrm{O}$ domenima.

U istraživanju Kolete van Dam A i O domeni su uspešno razlikovali prekršioce i subjekte iz kontrolne grupe (pet faktora su mereni pomoću Short Big Five Questionary, Gerris et al., 1998 po van Dam et al., 2005). Prekršioci su imali značajno niže skorove na oba faktora ličnosti u odnosu na kontrolnu grupu. U ovoj studiji, nijedan od faktora nije uspeo da diskriminiše recidiviste i nerecidiviste kada su u pitanju zvanični policijski podaci. Međutim, kada je recidivizam bio meren preko self-report izveštaja, pokazalo se da recidivisti imaju značajno izraženiji Neuroticizam i značajno niže skorove na A faktoru (van Dam et al., 2005). Podaci koje pružaju Klovel i Botvel su drugačiji. Oni su u svom istraživanju dobili da recidivisti postižu značajno niže skorove na $\mathrm{C}$ i $\mathrm{O}$ domenima ličnosti, sa značajnom interakcijom između njih, kada je u pitanju recidivizam kao zavisna varijabla (Clower \& Bothwell, 2001). Osobe sa niskom Savesnošću ne umeju da organizuju i isplaniraju svoje akcije, teško odlažu potkrepljenje, neoprezne su i nemarne i zbog toga lakše bivaju ponovo uhvaćene od strane policije, te ne začuđuje nizak skor na $\mathrm{C}$ domenu kod recidivista. Sniženu Otvorenost za iskustvo u ovoj grupi ispitanika istraživači objašnjavaju na dva načina. Kako je O jedini domen petofaktorskog modela koji pokazuje sistematske pozitivne korelacije sa inteligencijom (Costa \& McCrae, 1995), autori pretpostavljaju da osobe koje se ponovo upuštaju u krivična dela i bivaju uhvaćene funkcionišu sa sniženim intelektualnim kapacitetima. Sa druge strane, ovaj faktor je slabije izražen kod lica nižeg socioekonomskog statusa, odnosno onih osoba koje poseduju veću verovatnoću uključivanja u kriminogene aktivnosti, što zbog realne potrebe za novcem, što, kako autori smatraju, zbog povećane verovatnoće identifikovanja sa kontrakulturom, a samim tim i kriminogenim stilom kao jednim od tokova koji u njoj egzistira (Clower \& Bothwell, 2001).

Hejven je kroz dve studije pokušao da identifikuje i precizira odnose između Velikih pet i kriminaliteta. U prvoj studiji posmatrane su povezanosti između pet faktora i nasilničkog ponašanja kao i vandalizma i krađa (združenih u jednu kategoriju) posebno za muškarce i žene (Heaven, 1996). Faktor A je bio negativno povezan sa nasiljem kroz oba pola (-0,46 muškarci i $-0,19$ žene) kao i sa vandalizmom i krađama, ali samo kod muškaraca $(-0,36)$. C faktor nije bio značajno povezan sa nasiljem ali jeste sa vandalizmom i krađama (-0,28 muškarci i -0,21 žene). $\mathrm{N}$ domen pozitivno korelira sa nasilničkim ponašanjem kod žena $(0,20)$ i vandalizmom i krađama kod muškaraca $(0,24)$. U drugoj studiji autor je hteo da precizira ove povezanosti tako što je zadavao facete faktora za koje je smatrao da treba da budu nosioci ovih povezanosti sa kriminoge- 
nim ponašanjem (Petofaktorski model je hijerarhijski organizovan. Velikih pet su najširi, robustni i bazični domeni ličnosti. Oni se granaju u facete, subfaktore koji ih preciznije opisuju, a ovi se onda ispoljavaju u mnoštvu specifičnih oblika ponašanja.). Iako generalni domen Ekstraverzije nije značajno korelirao sa kriminalitetom Hejven je zadao i aspekte ovog domena Asertivnost i Potragu za uzbuđenjima.

Rezultati su bili sledeći: što se $\mathrm{C}$ domena tiče, nedostatak Samodiscipline je najvažniji generator vandalizma i pljačkanja $(-0,29)$. Svi faceti A domena koji su testirani u modelu su bili značajno negativno povezani sa kriterijumskim ponašanjem: pre svega Poverenje ( $-0,34$ za nasilje i $-0,31$ za vandalizam/krađe), zatim Altruizam $(-0,31$ i $-0,27)$ i na kraju Blaga narav $(-0,25$ za nasilje). Iako domen $E$ nije značajno korelirao sa kriminogenim ponašanjem, njegov aspekt Potrage za uzbudenjem ostvaruje pozitivne korelacije $(0,22$ i 0,26$)$. Suprotna situacija je sa $\mathrm{N}$ faktorom. Generalno on pozitivno korelira sa kriterijumskim ponašanjem ali njegovi aspekti Hostilnost i Impulsivnost ne.

Važan nalaz ovog istraživanja je potvrda značaja nedostatka poverenja kao faktora koji učestvuje u produkciji kriminaliteta. Ovaj podatak je konzistentan sa nalazima Krugera i saradnika (Krueger et al., 1994) o povezanosti Alijenacije iz Telegenovog modela i kriminogenog ponašanja (tabela 2). Poverenje je i najvažniji prediktor od svih ispitivanih varijabli u postavljenom regresionom modelu (Heaven, 1996). Korelacije između Potrage za uzbuđenjem i kriminaliteta su takođe potvrda Zakermanovih stanovišta o povezanosti Traženja senzacija i ovakvog ponašanja (Zukerman, 2007). Ono što je začuđujuće je da crte Hostilnosti (osećaj gneva, frustriranosti, iritiranosti) i Impulsivnosti kao faceti $\mathrm{N}$ domena nisu bili pozitivno povezani sa kriminalitetom pošto smo već govorili da se ovakve povezanosti uglavnom dobijaju u drugim istraživanjima.

Nešto drugačija situacija je kada su u pitanju prekršioci koji se upuštaju u seksualne delikte, usmerene protiv dece i adolescenata. Denison i saradnici su zadavali NEO-PI-R (jedan od instrumenata za eksploraciju Petofaktorskog modela ličnosti koji meri i pojedinačne facete svih domena) prekršiocima na izdržavanju zatvorske kazne zbog seksualnih delikata izvršenih protiv dece i adolescenata, i kontrolnoj grupi ispitanika. Prekršioci su bili razvrstani u tri grupe: oni koji su vršili incestuozne činove u primarnoj porodici, prekršioci iz usvojeničkih ili starateljskih porodica i seksualni prekršioci koji su vršili delikte van porodične sredine. Prekršioci su postigli značajno viši skor u odnosu na kontrolnu grupu na N domenu i na sledećim facetima ovog domena: Anksioznost, Depresivnost, Socijalna nelagodnost i Vulnerabilnost (Dennison et al., 2001). Značajno niže skorove prekršioci su postigli na faktorima $E$ (faceti: Druželjubivost i Asertivnost) i C (faceti: Kompetencija i Promišljenost). Ovi 
nalazi daju nam prilično precizan opis ličnosti pedofila. To su osobe sklone depresivnim doživljavanjima, u društvu se osećaju nelagodno pa stoga i nemaju potrebu da puno vremena provode sa drugim ljudima. Osećaju se lako povredljivim, napetim i sebe doživljavaju kao skromne osobe, blage naravi. Smatraju sebe nekompetentnim i nemaju poverenja u svoje sposobnosti. Niske su asertivnosti i nepromišljeni su.

Nakon toga izvršena je diskriminativna analiza. Generisana je jedna diskriminativna funkcija koja je značajno razdvajala ispitanike i predviđala pripadnost subjekata kriterijumskim ili kontrolnoj grupi. Varijable koje razdvajaju ispitanike u grupe su upravo one na kojima su postignute značajne razlike između grupa, tako da su rezultati diskriminativne i analize varijanse potpuno kongruentni (u diskriminativnoj funkciji se pojavljuju i dva faceta domena A: Skromnost i Blaga narav). U sledećim tabelama date su korelacije crta ličnosti sa generisanom funkcijom, kao i rezultati predikcije pripadnosti ispitanika grupama pomoću nje.

Tabela 4. Crte ličnosti koje konstituišu diskriminativnu funkciju pri predikciji pripadništva grupi seksualnih prekršilaca (prikazani su samo faceti koji u najvećoj meri koreliraju sa diskriminativnom funkcijom). Preuzeto iz Dennison et al., 2001.

\begin{tabular}{lll}
\hline & \multicolumn{1}{c}{ Diskriminativna funkcija } \\
\hline Faktori kojima faceti & Crte ličnosti- faceti faktora & Korelacija sa diskriminativ- \\
pripadaju & Velikih pet & nom funkcijom \\
\hline N3 & Depresivnost & .49 \\
N4 & Socijalna nelagodnost & .45 \\
A5 & Skromnost & .42 \\
C1 & Kompetencija & -.38 \\
N6 & Vulnerabilnost & .35 \\
C6 & Promišljenost & -.30 \\
E3 & Asertivnost & -.28 \\
A6 & Blaga narav & .27 \\
N1 & Anksioznost & .25 \\
E2 & Druželjubivost & -.24 \\
\hline
\end{tabular}

Jasno je da na osnovu ranije izloženih podataka ovo nije struktura ličnosti koja odlikuje prekršioce uopšte. Nema standardnih padova na C i A domenima, štaviše stiče se utisak da je povišenje na $\mathrm{N}$ domenu i snižen $\mathrm{E}$ faktor jezgro ličnosti seksualnih prekršilaca. Upadljivo je takođe da Impulsivnosti i agresivnosti nema kao crta koje značajno koreliraju sa diskriminativnom funkcijom, a to su osobine ličnosti koje po većini istraživanja učestvuju u generisanju kriminogenog ponašanja. Izgleda da iako su nepromišljene (verovatno u smis- 
lu neopreznosti), ove individue nemaju teškoća sa kontrolom Impulsa. Osećaj odbacivanja i doživljaj sopstvene nekompetentnosti je verovatno uzrok zašto ovakve osobe ne mogu da formiraju bliske veze sa drugima i da ih zadrže, na šta utiče i generalna socijalna introvertnost i nedruželjubivost. Ove tendencije verovatno stvaraju potrebu da seksualni prekršioci traže i ostvaruju veze sa decom i adolescentima, jer se tu osećaju u manjoj meri neadekvatno, dobijaju poštovanje i lakše stiču kontrolu i ostvaruju dominaciju (Finkelhor, 1984, po Dennison et al., 2001).

Tabela 5. Rezultati klasifikovanja ispitanike u grupe na osnovu diskriminativne funkcije generisane pomoću crta ličnosti Petofaktorskog modela (faceta). Preuzeto iz Dennison et al., 2001.

\begin{tabular}{|c|c|c|c|c|c|}
\hline \multirow[t]{2}{*}{ Grupe ispitanika } & \multicolumn{5}{|c|}{ Predviđena pripadnost grupi } \\
\hline & $\mathrm{N}$ & $\begin{array}{l}\text { Kontrol- } \\
\text { na grupa }\end{array}$ & $\begin{array}{l}\text { Incest u } \\
\text { prim. poro- } \\
\text { dici }\end{array}$ & $\begin{array}{l}\text { Incest u nep- } \\
\text { rim. porodici }\end{array}$ & $\begin{array}{l}\text { Izvan po- } \\
\text { rodice }\end{array}$ \\
\hline Kontrolna grupa & 33 & $30(90.9)$ & $0(0.0)$ & $1(3.0)$ & $2(6.1)$ \\
\hline $\begin{array}{l}\text { Incest u primarnoj } \\
\text { porodici }\end{array}$ & 17 & $1(5.9)$ & $9(52.9)$ & $0(0.0)$ & $7(41.2)$ \\
\hline $\begin{array}{l}\text { Incest u neprimar- } \\
\text { noj porodici }\end{array}$ & 11 & $1(9.1)$ & $1(9.1)$ & $8(72.7)$ & $1(9.1)$ \\
\hline Izvan porodice & 32 & $2(6.3)$ & $5(15.6)$ & $2(6.3)$ & $23(79.1)$ \\
\hline
\end{tabular}

Podaci u tabeli 5 pokazuju preciznost diskriminativne funkcije u razvrstavanju ispitanika u grupe. Osnovni nalaz nam govori da je model u stanju da diskriminiše prekršioce od neprekršilaca sa velikom tačnošću ( $91 \%$ ispitanika iz kontrolne grupe je zaista u nju i svrstano). Prediktivna moć je nešto slabija kada se tiče razvrstavanja među submodalitetima seksualnih prekršilaca. Preciznost je zadovoljavajuća kada su u pitanju osobe koje su izvršile seksualni delikt u hraniteljskoj ili usvojeničkoj porodici (73\% tačnosti) i prekršioci koji su vršili delikte izvan porodičnih okvira (79\%). Najveću grešku model pravi kada je u pitanju incestuozni delikt u primarnoj porodici (samo 53\% tačnih razvrstavanja) i to u korist vanporodičnih prekršilaca (gde je smešteno 41\% ovih ispitanika). Ipak podaci jasno govore da je Petofaktorski model bez sumnje validan i koristan teorijski okvir u eksploraciji strukture ličnosti osoba koje vrše seksualne delikte.

Jedna od pretpostavki na kojima počiva Petofaktorski model je i "hipoteza o racionalnosti." Samoprocena i procena drugih mogla bi se ostvariti jedino ako 
su ljudi u stanju da pored grešaka i predrasuda adekvatno opažaju važne osobine ličnosti kod sebe i drugih (socijalno ili uopšte adaptivno važne). Međutim, da li je ova hipoteza opravdana kada je u pitanju kriminogeno ponašanje? Osobe koje poseduju pro-kriminogene crte mogle bi pokušati da ih sakriju, ne samo od drugih već i od sebe, kako bi formirali sliku o sebi koja je usklađena sa socijalnim normama. Da bi dao odgovor na ovo pitanje Vajb je ispitao povezanost varijabli koje su merile tendenciju da se drugima pruži pogrešna slika o sebi (Varanje), tendenciju da se opravda sopstveno kriminogeno ponašanje (Neutralizacija) i promiskuitetnog ponašanja sa kriminalitetom. U istraživanju je takođe zadat i instrument koji meri domene Petofaktorskog modela ali u koji nisu uključene subskale odnosno faceti ${ }^{5}$.

Sve tri varijable koje je koncipirao Vajb značajno su pozitivno korelirale sa kriminogenim ponašanjem merenim preko skala samoprocene (Varanje: 0,30 za muškarce i 0,22 za žene; Neutralizacija: 0,51 i 0,41 i Promiskuitet: 0,38 za muškarce, korelacija u ženskom poduzorku nije bila statistički značajna). Od domena bazične strukture ponovo su $\mathrm{C}$ i A pokazali značajne negativne povezanosti sa kriminalitetom (Wiebe, 2004). Međutim, ono što je zaista Vajb hteo da sazna jeste da li tri specifične varijable ličnosti doprinose predviđanju kriminaliteta kada se u prediktivni model uvedu nakon faktora bazične strukture ličnosti, odnosno da li zahvataju varijansu koju Velikih pet ne objašnjavaju. Odgovor je bio potvrdan: uvođenje Varanja, Neutralizacije i Promiskuiteta u regresioni model preko bazičnih domena ličnosti povećava procenat objašnjene varijanse od $8 \%$ do $19 \%$ za žene i $17 \%$ do $37 \%$ za muškarce. Na osnovu ovoga autori zaključuju da se tri ispitivane crte nalaze van Petofaktorskog modela (Wiebe, 2004).

Značajnost laganja, ostavljanja pogrešnog utiska o sebi, racionalizacije i opravdavanja sopstvenih postupaka u objašnjenju kriminogenog ponašanja je nesumnjiva. Takođe, može se prihvatiti tvrdnja da ove crte leže van prostora opisanog pomoću pet velikih dimenzija ličnosti. Međutim, pitanje je da li ove tendencije leže zaista van bazične strukture ličnosti. Neki noviji nalazi sugerišu da upravo opisane ličnosne karakteristike mogu biti deo dimenzije Poštenje/Skromnost koja je deo Šestofaktorskog modela ličnosti (Lee \& Ashton, 2006).

\footnotetext{
${ }^{5}$ U pitanju je NEO FFI (Costa i McCrae, 1992).
} 


\section{Skromnost i poštenje}

Velikih pet faktora ličnosti su manje-više dosledno replicirani u studijama koje su koristile opise ličnosti bazirane na terminima iz Engleskog jezika ${ }^{6}$. Međutim, istraživanja na drugim jezicima ponudila su šest faktora kao adekvatnije rešenje strukture ličnosti (Ashton, Lee, Perugini, et al., 2004 po Lee et al., 2005). Ovaj model ličnosti nazvan je HEXACO, što predstavlja akronim za sledeće faktore: Poštenje/Skromnost (Honesty-Humility), Emocionalnost (Emotionality), Ekstraverzija (eXtraversion), Saradljivost (Agreableness), Savesnost (Conscientiousness) i Otvorenost (Openness). Faktori Ekstraverzije, Savesnosti i Otvorenosti predstavljaju pandane istoimenih faktora iz Petofaktorskog modela. Faktori Emocionalnosti i Saradljivosti predstavljaju rotirane faktore Neuroticizma i Saradljivosti: varijansa asocirana sa iritabilnošću (Hostilnošću) i sentimentalnošću je različito raspoređena u dva modela (de Vries et al., 2009).

Međutim, najveća razlika između dva modela je pojava šestog faktora ličnosti, nazvanog Poštenje/Skromnost (H). Ovaj faktor je i razlog zbog čega govorimo o HEXACO modelu i njegovom povezanošću sa kriminalitetom. Kako su istraživanja sa šestofaktorskim modelom ličnosti još uvek malobrojna, ukratko ćemo izložiti tri razloga zbog kojih smatramo da je $\mathrm{H}$ faktor izuzetno važan $\mathrm{u}$ objašnjenju kriminaliteta, od kojih su dva teorijske prirode.

Konceptualizacija samog faktora. Psihološki sadržaj ove dimenzije predstavljaju osobine ličnosti koje se tiču iskrenosti, poštenja i skromnosti, nasuprot manipulativnosti, pohlepi i pretencioznosti (de Vries et al., 2009). Jasno je da je $\mathrm{H}$ faktor generator varijanse koja je povezana sa moralno relevantnim ličnosnim tendencijama, odnosno crtama ličnosti koje su odgovorne za produkovanje ponašanja koja se ostvaruju u moralnom kontekstu. Mnoga istraživanja su pokazala da su ovakve crte ličnosti dosledni generatori amoralnog i kriminogenog ponašanja (Knežević, 2003).

Mračna trijada. Paulus je izdvojio tri crte ličnosti iz spektra osobina koje su odgovorne za agresivna, manipulativna, i kriminogena ponašanja. Nazvao ih je Mračna trijada ličnosti i ona se sastoji iz Makijavelizma, subkliničke Narcisoi-

\footnotetext{
${ }^{6}$ U leksičkim proučavanjima jezika razlikuju se dve globalne strategije: etska i emska. U prvoj se iz jednog jezika izdvoje termini za koje se smatra da adekvatno opisuju ličnost, zatim se oni faktorišu i krajnjom selekcijom termina sa dobijaju stabilni faktori i na njima grade instrumenti. Potom se ti instrumenti prevode na druge jezike i zadaju ispitanicima različitih govornih područja. U emskim studijama se opisi ličnosti ne prevode na druge jezike već se iz rečnika svakog jezika na čijem se govornom području želi vršiti istraživanje traže termini i potom se oni faktorišu. Model koji sadrži šest faktora nastaje u emskim studijama ličnosti.
} 
dnosti i subkliničke Psihopatije (Paulhus and Williams, 2002). Pokazano je da su ove osobine česti konstituenti strukture ličnosti kriminalaca, što se posebno odnosi na psihopatiju (Hemphill, Hare, \& Wong, 1998; Walters, 2003, po DeMatteo et al, 2005).

U istraživanju Lija i Aštona (Lee and Ashton, 2005) nađene su umerene negativne korelacije između faktora Saradljivosti iz Petofaktorskog modela i Psihopatije $(-0,39)$ kao i Makijavelizma i Psihopatije $(-0,44)$. Narcizam korelira pozitivno sa Ekstraverzijom $(0,49)$. Međutim, u istoj studiji su potvrđene visoke korelacije Mračne trijade i faktora Poštenja iz HEXACO modela kao i svih njegovih faceta. Ti rezultati prikazani su u sledećoj tabeli:

Tabela 6. Korelacije između Mračne trijade ličnosti (psihopatija, makijavelizam i narcisoidnost) i faktora Poštenja/Skromnosti i njegovih faceta. Podaci preuzeti iz Lee and Ashton, 2005.

\begin{tabular}{llll}
\hline & $\begin{array}{l}\text { Primarna Psiho- } \\
\text { patija }\end{array}$ & Makijavelizam & Narcisoidnost \\
\cline { 2 - 4 } Faktor Poštenje/Skromnost & -.72 & -.57 & -.53 \\
Faceti faktora Poštenje/Skromnost & & \\
Poštenje & -.75 & -.61 & -.32 \\
Iskrenost & -.57 & -.44 & $-.22^{*}$ \\
Izbegavanje pohlepe & -.49 & -.31 & -.48 \\
Skromnost & -.62 & -.50 & -.62 \\
\hline
\end{tabular}

*Jedina korelacija koja nije statistički značajna

Kao što se može videti iz tabele 6 , domen Poštenja značajno korelira sa svim crtama Mračne trijade, ali takođe postoje sistematske značajne povezanosti i svih njegovih faceta sa ispitivanim varijablama. Takođe, izvršeno je predviđanje međusobnog kovariranja crta Mračne trijade pomoću njihovih povezanosti sa modelom Velikih Pet i HEXACO modelom. Petofaktorski model nije uspeo da predvidi korelacije varijabli unutar mračne trijade. Predikcije HEXACO faktora su se pokazale približnije opserviranim vrednostima, ali tek kad su u model bili uključeni faceti faktora Poštenja, predviđene korelacije su bile najbliže stvarnim (Lee and Ashton, 2005). Ovo jasno govori o eksplanatornoj vrednosti subdimenzija faktora Poštenja. Iz nalaza možemo zaključiti da postoji zajednički ličnosni denominator crta koje nazivamo mračnom trijadom, i posredno, preko ovog nalaza, da je faktor Poštenja bazična dimenzija ličnosti koja je u velikoj meri odgovorna za nastanak antisocijalnog i kriminogenog ponašanja.

Predviđanje delinkvencije na radnom mestu. Iako je dominantno rađeno $\mathrm{u}$ sferi poslovne psihologije, jedno drugo istraživanje Aštona i Lija može nam pružiti bar delimičnu empirijsku potvrdu o povezanosti faktora Poštenja i de- 
linkventnog ponašanja (Lee and Ashton, 2005). U ovoj studiji autori su uporedivali prediktivnu moć Petofaktorskog i HEXACO modela, kada je kriterijumska varijabla bila delinkvencija na radnom mestu. $U$ okviru ispitivanih modaliteta ponašanja, najmanje dva se mogu okarakterisati kao kriminogena: krađa i vandalizam. HEXACO je uspešnije predviđao delinkvenciju na radnom mestu od Velikih Pet, i ova uspešnost se skoro u potpunosti može pripisati faktoru Poštenja: kada se u modelu multiple regresije ovaj faktor doda kao prediktor na velikih pet, procenat objašnjene varijanse u proseku je rastao za 14\% (Lee and Ashton, 2005).

\section{Umesto zaključka, još istraživačkih pitanja}

Neosporna je povezanost bazične strukture ličnosti i kriminogenog ponašanja. Svi modeli bazične strukture pokazuju se sposobnim da objasne i predvide varijansu kriminogenog i antisocijalnog ponašanja. Kako postoji veliki broj konstrukata i njihovih operacionalizacija, pred istraživače se postavljaju dva važna pitanja kada je reč o odnosu ličnosti i kriminala.

Prvi je izdvajanje faktora iz različitih modela bazične strukture koji su konzistentni i stabilni prediktori kriminogenog ponašanja i onih koji to nisu (npr: Psihoticizam iz PEN modela; Agresivnost i Tradicionalizam iz Telegenovog; Saradljivost i Savesnost iz Velikih pet; Poštenje iz HEXACO modela). Potom bi trebalo izvršiti uklanjanje zajedničke varijanse ovih konstrukata, odnosno precizirati koji je doprinos svakog od ovih konstrukata objašnjavanju kriminaliteta.

Ovo je veliki posao, jer kako je već rečeno postoji veliki broj modela bazične strukture ličnosti. Važno je ipak primetiti da se konstrukti ekstrahovani u ovim modelima (bar kada govorimo o faktorskim teorijama ličnosti), u velikoj meri preklapaju, iako faktori nose različita imena. Još jedna olakšavajuća okolnost je što za većinu njih postoji dovoljan broj empirijskih nalaza koji omogućuju da se ovakav posao izvrši. Ipak, ponekad se čini da se u svoj toj šumi modela jako teško snaći. Neki modeli, kao što je HEXACO, ne povećavaju entropiju u ovom sistemu konstrukata, već samo količinu informacije, odnosno saznajne i prediktivne moći. Sa druge strane postoje leksički modeli ličnosti koji se u većoj meri razlikuju od konsenzusa postignutog sa Velikih pet kao što je Sedmofaktorski model ličnosti (Almagor et al.,1995). Ipak, ni on se ne može izuzeti iz analize koja povezuje bazičnu strukturu ličnosti i kriminalitet, jer faktor ekstrahovan u okviru Velikih Sedam, nazvan Negativna valenca takođe opisuje amoralna, manipulativna i prevrtljiva ponašanja (Almagor et al.,1995), te se mora pretpostaviti njegova povezanost sa kriminogenim 
ponašanjem. Iako zadatak izgleda vrlo težak, čini se da je ipak moguće postići konsenzus o odnosu bazične strukture ličnosti i kriminaliteta poput onog koji već postoji o samim bazičnim dimenzijama ličnosti.

Kada se jednom uspostavi određeni stepen saglasnosti koji se tiče teorijskog modela za eksploraciju udela koji ličnost ostvaruje u kriminogenom ponašanju, treba obratiti veću pažnju specifičnostima samog kriminalnog akta. Neke važne varijable su već pomenute: pre svega tip krivičnog dela (nalazi o kojima je raspravljano govore da se crte ličnosti koje generišu lakša krivična dela razlikuju od onih koje čine strukturu ličnosti silovatelja ili ubica npr.), udeo polnih razlika, starosti prekršioca i, kada je reč o stabilnosti kriminogenog ponašanja, crte koje pokreću individuu ponovo u zločin (odnosno recidiv). Međutim, najviši stepen integracije bez sumnje bi predstavljalo povezivanje crta ličnosti sa uticajem sredine, odnosno ispitivanje njihove zajedničke uloge $u$ fenomenu kriminaliteta (poput nalaza o odnosu crte Impulsivnosti i ekonomske razvijenosti naselja u kojima prekršioci žive, Lynam et al., 2001 po Zuckerman, 2007). I na kraju, značaj maloletničke delinkvencije kao društvenog problema i njegovog učešća u kriminogenom ponašanju uopšte, zahteva da proučavanja interakcije ličnosti i sredine poseduju i razvojnu dimenziju.

\section{Reference:}

Almagor, M., Tellegen, A. and Waller, N.G. (1995). A Cross-Cultural Replication and Further Exploration of the Basic Dimensions of Natural Language Trait Descriptors. Journal of Personality and Social Psychology, Vol. 69, No. 2, 300-307.

Cale, E.M. (2006). A quantitative review of the relations between the "Big 3" higher order personality dimensions and antisocial behavior. Journal of Research in Personality, 40, 250-284.

Clower, C. E. and Bothwell, R. K. (2001). An Exploratory Study of the Relationship between the Big Five and Inmate Recidivism. Journal of Research in Personality, 35, 231-237.

Costa, P. T. and McCrae, R. R. (1992). Revised NEO Personality Inventory (NEO-PI-R) and NEO Five-Factor Inventory (NEO-FFI) Professional Manual. Odessa: Psychological Assessment Resources. Inc.

Costa, P. T. Jr., and McCrae, R. R. (1995). Primary Traits of Eysenck's P-E-N System: Three- and Five-Factor Solutions. Journal of Personality and Social Psychology, Vol. 69, No. 2, 308-317. 
Dennison, S.M., Stough, C. and Birgden, A. (2001). The big 5 dimensional personality approach to understanding sex offenders. Psychology, crime $\mathcal{E}$ law, Vol. 7, 243-261.

DeMatteo, D., Heilbrun, K. and Marczyk, G. (2005). Psychopathy, Risk of Violence, and Protective Factors in a Noninstitutionalized and Noncriminal Sample. International Journal of Forensic Mental Health, Vol. 4, No. 2, pages 147-157.

de Vries, R. E., de Vries, A., Feij, J. A. (2009). Sensation seeking, risk-taking, and the HEXACO model of personality. Personality and Individual Differences, vol 47, 536-540.

Eysenck, H. J. (1996). Personality and crime: Where do we stand. Psychology, Crime E Law, 2, 143-152.

Eysenck, H. J., \& Gudjonsson, G. H. (1989). The causes and cures of criminality. New York: Plenum.

Eysenck, H. J., \& Eysenck, S. B. G. (1976). Psychoticism as a dimension of personality. London: Hodder \& Stoughton.

Heaven, P. C. L., Newbury, K., Wilson, W. (2004). The Eysenck psychoticism dimension and delinquent behaviours among non-criminals: changes across the lifespan? Personality and Individual Differences, 36, 1817-1825.

Heaven, P. C. L. (1996). Personality and self-reported delinquency: Analysis of the "Big Five" personality dimensions. Personality and individual differences Vol. 20. No. I, pp. 47-54.

Hollin, C. (1989). Psychology and crime: An introduction to criminological psychology. New York: Routledge.

Horvath, P. and Zuckerman, M. (1993). Sensation Seeking, Risk Appraisal, and Risky Behavior. Personality and Individual Differences, 14, 41-52.

John, O. P., Caspi, A., Robins, R. W., Moffitt, T. E., \& Stouthamer-Loeber, M. (1994). The "little five": exploring the nomological network of the fivefactor model of personality in adolescent boys. Child Development, $65,160-178$.

Knust, S. and Stewart, A.L. (2002). Risk-taking behaviour and criminal offending: An investigation of Sensation Seeking and the Eysenck Personality Questionnaire. International Journal of Offender Therapy and Comparative Criminology, 46(5), 586-602. 
Krueger, R.F., Schmutte, P.S., Caspi, A., Moffitt, T.E., Campbell, K. and Silva, P.A. (1994). Personality Traits Are Linked to Crime Among Men and Women: Evidence From a Birth Cohort. Journal of Abnormal Psychology, Vol. 103, No. 2, 328-338.

Knežević, G., Džamonja Ignjatović, T., Jočić, D.Đ. (2004). Petofaktorski model ličnosti. Centar za primenjenu psihologiju, Beograd.

Knežević, G. (2003): Koreni amoralnosti. Institut za kriminološka i sociološka istraživanja, Institut za psihologiju, Beograd.

Lee, K. and Ashton, M. C. (2006). Further Assessment of the HEXACO Personality Inventory: Two New Facet Scales and an Observer Report Form. Psychological Assessment Vol. 18, No. 2, 182-191.

Lee, K., Ashton, M. C., de Vries, R. E. (2005). Predicting Workplace Delinquency and Integrity with the HEXACO and Five-Factor Models of Personality Structure. Human Performance, 18(2), 179-197.

Lee, K. and Ashton, M. C. (2005). Psychopathy, Machiavellianism, and Narcissism in the Five-Factor Model and the HEXACO model of personality structure. Personality and Individual Differences 38, 1571-1582.

Miller, J. D. \& Lynam, D. (2001). Structural models of personality and their relation to antisocial behavior: a meta-analitic rewiev. Criminology, 39, 765-798.

Moffitt, T.E., Caspi, A., Dickinson, N., Silva P., Stanton, W. (1996). Childhood -onset versus adolescent-onset antisocial conduct problems in males: natural history from ages 3 to 18 years. Development and Psychopatology, 8, 399-424.

Patrick, C.J., Curtin, J.J., Tellegen, A. (2002). Development and Validation of a Brief Form of the Multidimensional Personality Questionnaire. Psychological Assessment, Vol. 14, No. 2, 150-163.

Paulhus, D. L. and Williams, K. M. (2002). The Dark Triad of personality: Narcissism, Machiavellianism, and psychopathy. Journal of Research in Personality 36 (2002) 556-563.

Romero, E., Luengo, M.A., Sobral, J. (2001). Personality and antisocial behaviour: study of temperamental dimensions. Personality and Individual Differences, 31, 329-348.

Saucier, G. (2008). Measures of the personality factors found recurrently in human lexicons. U G. J. Boyle, G. Matthews, D. H. Saklofske (Ed.) The 
SAGE handbook of personality theory and assessment, Volume 2 (pp 2954), London, SAGE Publications Ltd.

Tellegen, A. and Waller, N.G. (2008). Exploring personality through test construction: development of the Multidimensional personality questionnaire. U G. J. Boyle, G. Matthews, D. H. Saklofske (Ed.) The SAGE handbook of personality theory and assessment, Volume 2 (pp 261-292), London, SAGE Publications Ltd.

Van Aken, M. A. G., van Lieshout, C. F. M., \& Scholte, R. H. J. (1998). The social relationships and adjustment of the various personality types and subtypes. In Paper presented at the VIIth biennial meeting of the Society of Research on adolescence, San Diego, CA.

van Dam, C., Janssens J.M.A.M., De Bruyn, E.E.J. (2005). PEN, Big Five, juvenile delinquency and criminal recidivism. Personality and Individual Differences, 39, 7-19.

Wiebe, R.P. (2004). Delinquent behavior and the Five factor model: Hiding in the adaptive landscape? Individual differences research, 2 (l), 38-62.

Zuckerman, M. (2007). Sensation seeking and risky behavior. Washington DC: American psychological association.

Zuckerman, M. (1994). Behavioral expressions and biosocial bases of sensation seeking. New York: Cambridge University Press. 


\title{
Abstract
}

\section{BASIC PERSONALITY STRUCTURE AND CRIMINALITY}

\author{
Janko Međedović
}

Over the last two decades, personality has been one of the most important explanatory constructs in criminology. While examining personality traits which generate criminogenic and antisocial behavior, special attention is given to basic personality traits. The existing models of the basic personality structure are mostly robust, based on empirical data and various theoretical concepts. There are numerous data about the connection between the basic personality structure and different types of criminal behaviour. These data are relatively consistent and replicable.

This paper presents several models of the basic personality structure, as well as research related to the connection between these models and criminal behaviour. Hans Eysenck's theory is presented first, because of its important role in criminology research in the 1960s and 1970s. The paper also presents Tellegen's model, and the work of Marvin Zuckerman considering sensation seeking. However, special attention is given to the Five-Factor personality model, as the dominant concept related to examining personality today. As described in the paper, this model proves to be a successful explanatory construct in the field of criminology as well. At the end of the paper, HEXACO model is presented, with the emphasis placed on the Honesty/Humility factor, as a promising concept for the future research into the relationship between basic personality traits and criminal behaviour.

Key words: basic personality traits, criminal, antisocial behavior

Primljeno: 11.11.2009; prihvaćeno za štampu: 18.12.2009. 